\title{
Motorfietsbedryf: Geleenthede vir markontwikkeling
}

\author{
D. Lessing \\ Departement Bedryfsekonomie, Randse Afrikaanse Universiteit, Posbus 524, Johannesburg 2000, Republiek van Suid-Afrika
}

\author{
Ontvang Julie 1986; aanvaar 4 November 1986
}

\begin{abstract}
Motor-cycle industry: Opportunities for market development. The South African motor-cycle industry has experienced a constant decline in sales since 1981, that is, a drop from 84000 units sold during 1981 to a sales figure of 24509 units for 1985 . This decline in sales poses a threat to the profitability and survival of the motor-cycle industry in South Africa. Up to this point in time the marketing efforts of the motor-cycle industry were mainly directed towards the white consumer market. In order to bring about an uptum in motor-cycle sales. this study looked into the feasibility of a marketing effort by the motor-cycle industry aimed at the black consumer market. The findings of the study revealed that blacks currently view motor-cycles as a dangerous means of transport, used mainly by high speeding dare-devils. However, by the compilation of an optimum marketing strategy, the motor-cycle industry should be able to overcome the above-mentioned objection of blacks against motor-cycles. The marketing mix strategy should reveal the following characteristics: (i) A marketing communication strategy which centres on the re-education of blacks, so that they perceive motor-cycles as an economical means of transport, requiring little parking space, instead of as heavy metal terrorists' with a horrifying accident record. (ii) A product offered to the black market which reveals its economical characteristics and, as preferred by blacks, is in the commuter class $\left(200 \mathrm{~cm}^{3}-500 \mathrm{~cm}^{3}\right)$. (iii) A price that does not exceed R4000. (iv) The establishment of distribution outlets in white industrial areas with predominantly white sales personnel.
\end{abstract}

Die winsgewende voortbestaan van die Suid-Afrikaanse motorfietsbedryf word bedreig deur ' $n$ konstante daling in motorfietsverkope sedert 1981. Tans bestaan die motorfietsbedryf se verkope hoofsaaklik uit verkope aan die blanke mark. Weens die konstante daling in motorfietsverkope blyk dit dat die blanke mark in die huidige ekonomiese klimaat nie oor die potensiaal beskik om 'n styging in motorfietsverkope teweeg te bring nie. Gevolglik word die motorfietsbedryf genoodsaak om na nuwe markte vir hul produkte te soek. Die mees ooglopende mark om vir hierdie doel te selekteer, is die swart mark. Hierdie studie is onderneem om die lewensvatbaarheid, al dan nie, van die motorfietskonsep in die swart mark te toets. Dit blyk dat die swart mark wel vatbaar is vir die motorfietskonsep, mits die negatiewe ingesteldheid wat swartes teenoor ' $n$ motorfiets het afgetakel kan word. Die negatiewe ingesteldheid spruit voort uit die gevaarkonnotasie wat swartes aan 'n motorfiets heg. Deurdat die motorfietsbedryf 'n bemarkingsresepstrategie, met die volgende eienskappe ontwikkel, behoort hulle in staat te wees om die negatiewe ingesteldheid wat swartes teenoor motorfietse het af te takel, en dus suksesvol tot die swart mark toe te tree: (i) 'n Motorfiets in die pendelaarsklas $\left(200 \mathrm{~cm}^{3}-\right.$ $500 \mathrm{~cm}^{3}$ ) wat brandstofekonomies funksioneer. (ii) Handelaars wat in industriéle gebiede geleé is, waar baie swartes werksaam is. (iii) Die daarstelling van bemarkingskommunikasie-inligting wat daarop gerig is om swartes se beskouing van ' $n$ motorfiets te heroriënteer, en wel vanaf 'n gevaarlike vervoermiddel na 'n vervoermiddel wat mededingend is met alle ander vorme van vervoer op grond van ekonomie, tydsbesparing, en gerief, asook die swart huisgesin in staat stel om 'n eie vervoermlddel te besit. (iv) Motorfietse met pryse laer as $\mathrm{R} 4000$, veral weens swartes se relatiewe lae jaarlikse inkomste.

\section{Inleiding}

'n Aantal jare gelede het stygings in die brandstofprys die motorfietsbedryf merkbaar beïnvloed. Namate die brandstofprys verhoog het, veral tydens drastiese verhogings, het die verkope van motorfietse gestyg. Alhoewel die brandstofprys steeds besig is om te styg, blyk dit dat motorfietsverkope sedert 1981 'n konstante daling getoon het. Kyk Tabel 1.

Uit Tabel 1 blyk die daling in die afgelope vier jaar se motorfietsverkope duidelik. Die volgende faktore het bygedra tot die daling in motorfietsverkope die afgelope aantal jare:

(a) Die eskalerende inflasiekoers;

(b) die daling in die goudprys;

(c) die afname in verbruikersbesteding; en

(d) die nadelige Rand-/Dollar-/Yenwisselkoers op die wêreldvalutamark (Winfield, 1985:131).

As gevolg van die konstante daling in motorfietsverkope sal die motorfietsbedryf 'n daadwerklike poging moet aanwend om die voortbestaan van die bedryf te verseker, en te regverdig. Tans bestaan motorfietsverkope hoofsaaklik uit verkope aan die blanke mark. Dus blyk dit dat die potensiaal van die blanke mark nie voldoende is om 'n opswaai in motorfietsverkope gedurende die huidige ekonomiese klimaat teweeg te bring nie.

Ten spyte van die bedreiging wat die daling in verkope

Tabel 1 Jaarlikse motorfietsverkoopsyfers vanaf Januarie 1979 tot Desember 1985

Periode

Eenhede verkoop

Januarie tot Desember 1979

40000

Januarie tot Desember 1980

73809

Januarie tot Desember 1981

84000

Januarie tot Desember 1982

61591

Januarie tot Desember 1983

47780

Januarie tot Desember 1984

37681

24509

Bron: Persoonlike onderhoud met A. Heinz, gewese Streekswoorsituter - Suid-Transvaalstreek van die Motorfietsinvoenders en Handelanan Vereniging (MCIDA). 
vir die motorfietsbedryf inhou, is daar nog nie 'n daadwerklike poging aangewend om die potensiaal van die swart mark te ontgin nie. Die volgende aanhaling ondersteun hierdie stelling, naamlik: ' $\ldots$ in these times of reform and constructive engagement, we still have the hangover of motor-cycle apartheid. The persistent marketing of motor-cycles to white materialistic proclivities has ignored the largest potential market in the country - the blacks.'(Winfield, 1985:133).

Alhoewel die motorfietsbedryf van mening is dat swartes uit die aard van hul kultuur gekant is teen die gebruik van motorfietse as vervoermiddels, kan die volgende faktore 'n verandering in swartes se beskouing van motorfietse teweegbring, naamlik:

(a) Die konstante verhoging in brandstofpryse;

(b) die snelle verandering in die lewenstyl van swartes weens die verwesterliking van hierdie bevolkingsgrnep; en

(c) die behoefte aan 'n eie vervoermiddel.

Die voorgaande drie faktore het aanleiding gegee tot die ontwikkeling van 'n navorsingsprojek met die volgende oogmerke:

(a) Om inligting aan die motorfietsbedryf beskikbaar te stel aangaande swartes se gevoel teenoor die gebruik van motorfietse as vervoermiddels. Dus, is die studie onderneem om te bepaal of swartes, in die algemeen beskou, positief of negatief ingestel is teenoor die gebruik van motorfietse as vervoermiddels, asook die primêre rede vir hetsy hul positiewe of negatiewe ingesteldheid teenoor motorfietsvervoer.

(b) Om inligting aan die motorfietsbedryf beskikbaar te stel ten opsigte van swartes se motorfietsverwante voorkeure en behoeftes, soos byvoorbeeld hul enjinkapasiteitsvoorkeure, afsetpuntvoorkeure, prysvoorkeure en bemarkingskommunikasiemediavoorkeure.

Dit het op navraag geblyk dat 'n navorsingsprojek met die voorgaande doelwitte wel belangrike inligting aan die motorfietsbedryf beskikbaar kan stel aangesien 'n soortgelyke studie tot en met April 1985 nog nie in Suid-Afrika onderneem is nie. Alhoewel meningsopnames in hierdie verband wel in die buiteland gedoen is was die omvang daarvan gering en kon geen noemenswaardige gevolgtrekking of afleidings vanuit die bevindings gemaak word nie. Voorts is die omstandighede en behoeftes van die oorsese swarte so ver verwyderd van die Suid-Afrikaanse swarte dat gevolgtrekkings vanuit oorsese navorsingsbevindings totaal misleidend van aard sal wees.

Teen die agtergrond van die voorgaande bespreking word die bepaling van die steekproef wat getrek moes word ten einde die gestelde doelwitte van die navorsingsprojek te bereik vervolgens beskryf.

\section{Steekproef}

As uitgangspunt by die bepaling van die steekproef is streek negentien volgens die Standaard kodelys vir statistiese hoofstreke en streke, landdros-I magistraatsdistrikte, stede, dorpe en nie-stedelike gebiede geselekteer. Die. volgende magistraatsdistrikte is by die statistiese hoofstreek negentien ingesluit: Johannesburg, Randburg, Germiston, Alberton, Kemptonpark, Boksburg, Benoni, Brakpan, en Springs.

Hierdie streek is om twee redes geselekteer, naamlik:

(a) Sowat $45-50 \%$ van die motorfietsbedryf se huidige mark is in die betrokke streek gelee (Booyens). Die betrokke streek is dus aangewese vir die loodsing van die markondersoek aangesien dit bykans $50 \%$ van die motorfietsbedryf se totale mark verteenwoordig.

(b) Daar is ongeveer 1649528 swartes in hierdie streek met die implikasie dat dié streek een van die dig bevolkste stedelike gebiede in Suid-Afrika is (Sentrale Statistiekdiens, 1985). Weens die verligting wat motorfietsvervoer kan bring ten opsigte van aspekte soos verkeersknope en parkeerprobleme is 'n dig bevolkte stedelike gebied meer vatbaar as ' $n$ lae bevolkte stedelike of plattelandse gebied vir die gebruik van motorfietse as vervoermiddels.

Ten einde die steekproefgrootte te bepaal is van die volgende aannames en gegewens gebruik gemaak, naamlik:

(a) Dat slegs $10 \%$ van die swartes in hierdie gebied positief ingestel is ten opsigte van motorfietse as vervoermiddels. As grondslag vir die betrokke beraming is die huidige verkope van motorfietse aan swartes gebruik. Alhoewel geen eksakte syfers in hierdie verband beskikbaar is nie het dit uit die subjektiewe raming van motorfietsverkope aan swartes geblyk dat die aanvanklike $10 \%$ raming eerder optimisties as pessimisties is, in welke geval dit geen afbreuk aan die betroubaarheid van die steekproefresultate sal doen nie.

(b) Dat die steekproeftrekking gegrond moet wees op 'n $95 \%$ betroubaarheidskoëffisiẻnt.

(c) Dat daar op 31 Maart 1985, 42739 handelslisensies in die betrokke gebied uitgereik was. Die betrokke hoeveelheid handelslisensies is verkry deur 'n sommering van die aantal handelslisensies wat op die betrokke datum in elk van die magistraatsdistrikte uitgereik was. Hierdie inligting is vanaf die onderskeie munisipale kantore verkry.

(d) Dat die totale hoeveelheid ekonomies aktiewe swartes in die betrokke gebied op 31 Maart 1985, 753895 beloop het. Hierdie inligting is op 'n soortgelyke wyse as die inligting in punt (c) hierbo verkry.

(e) Dat slegs swartes wat meer as R8000 per jaar verdien by die steekproef ingesluit word. Hierdie aanname is gemaak aangesien die finansiele instellings van mening was dat slegs swartes wat R8000 per jaar of meer verdien, sal kwalifiseer vir huurkoopfinansiering.

(f) Dat slegs $25 \%$ van die swartes in die bepaalde streek R8000 per jaar of meer verdien. 'n Voorlopige ondersoek van swart werknemers se jaarlikse inkome wat by vyf ondernemings in die betrokke streek van stapel gestuur is het aangetoon dat die betrokke aanname weer eens optimisties is en dus 
geen afbreuk aan die betroubaarheid van die steekproefresultate sal doen nie.

Teen die agtergrond van die voorgaande aannames en gegewens kon die steekproefgrootte bepaal word aan die hand van die volgende formule wat deur Cochran (1963:75) daargestel is, naamlik:

$$
\begin{aligned}
N & =\frac{t^{2} p(1 \cdots p)}{d^{2}} \\
& =\frac{(1,96)^{2}(0,1)(0,9)}{(0,05)^{2}} \\
& \simeq \stackrel{140}{\longrightarrow}
\end{aligned}
$$

Waar $p=$ beraamde proporsie swartes wat positief ingestel is teenoor die gebruik van motorfietse as vervoermiddels, wat aanvaar word as $10 \% ; d=$ die presisie se waarde wat bepaal is as 0,05 aangesien daar met ' $n$ 95\% betroubaarheidskoëffisiënt gewerk word; $\alpha=$ die klein risiko wat die navorser bereid is om te aanvaar dat die werklike en beraamde proporsie met meer as $d$ se waarde sal verskil en in hierdie geval as 0,05 gekies is; $t- \pm 1,96$ volgens die normaaltabelle, omdat $\alpha=0,05$.

Aangesien dit besonder moeilik is om swartes te bereik is daar besluit om respondente deur middel van hul werkgewers te bereik. Gevolglik moes 'n aantal ondernemings in dié streek geselekteer word wat die daarstelling van die aannames en gegewens in punte (c) tot $(f)$ genoodsaak het.

Ter bepaling van die aantal ondernemings wat geselekteer moes word is daar soos volg te werk gegaan:

(a) Die aantal ekonomies aktiewe swartes wat R8000 per jaar of meer verdien is bepaal deur die aantal ekonomies aktiewe swartes met $25 \%$ te vermenigvuldig, naamlik: $753895 \times 25 \%=188$ 473.

(b) Die aantal ekonomies aktiewe swartes wat R8000 per jaar of meer verdien is gedeel deur die aantal handelslisensies uitgereik ten einde die gemiddelde aantal kwalifiserende swartes per onderneming te bepaal, naamlik: $188473 \div 42739=4,4$.

(c) Die aantal ondernemings wat geselekteer moes word is bepaal deur die antal vraelyste (140) wat voltooi moes word te deel met die gemiddelde hoeveelheid swartes wat $\mathrm{R} 8000$ per jaar of meer verdien, naamlik: $140 \div 4,4=32$ ondernemings.

Alle lisensieerbare ondernemings is by die munisipale kantore in die onderskeie magistraatsdistrikte, in numeriese volgorde, volgens standnommer gerangskik. Deur van ewekansige tabelle gebruik te maak, is ondernemings, pro rata, volgens die aantal ekonomies aktiewe swartes per magistraatsdistrik, geselekteer.

Deur die name van swart werknemers wat $R 8000$ per jaar of meer verdien, by die gekose ondernemings in die onderskeie magistraatsdistrikte te verkry, en te lys, is die respondente met behulp van ewekansige tabelle geselekteer. Die aantal vraelyste wat by die gekose ondernemings per magistraatsdistrik voltooi moes word is ook pro rata bepaal volgens die aantal ekonomies aktiewe swartes in die distrik. So byvoorbeeld moes daar 78 respondente gekies word uit die naamlyste van kwalifiserende werkers by die gekose 17 ondememings in die magistraatsdistrik van Johannesburg, terwyl slegs 10 respondente uit die naamlyste van twee ondememings in die magistraatsdistrik van Kemptonpark verkry moes word.

Die vraelyste is deur bemiddeling van die personeelbestuurders by die onderskeie ondernemings aan die werkers verskaf. Die vraelyste is na ongeveer een week persoonlik afgehaal en gekontroleer om te verseker dat alle vrae korrek voltooi is. In enkele gevalle waar vrae nie beantwoord is nie, is die respondent of per telefoon, of persoonlik genader om die verlangde antwoord op die vraag te verkry. Sodoende is verseker dat alle vrae, in die 140 vraelyste wat uitgereik is, korrek voltooi is.

Teen die agtergrond van die voorgaande bespreking van die steekproef kan die demografiese eienskappe van die steekproefrespondente vervolgens beskryf word.

\section{Demografiese eienskappe}

Aan die hand van die rekenaar verwerkte drukstuk van die vraelyste kon die demografiese eienskappe van die steekproefrespondente in Tabel 2 uiteengesit word.

Uit Tabel 2 blyk die demografiese eienskappe van die steekproefrespondente. Tydens die bestudering van die inligting moet in gedagte gehou word dat slegs swartes wat $R 8000$ per jaar of meer verdien by die steekproef ingesluit is.

Met die wyse van steekproeftrekking en die demografiese eienskappe van die steekproefrespondente gegewe kan daar oorgegaan word tot die weergee van die bevindings van die navorsingsprojek. Die bevindings van die navorsingsprojek word in die vorm van 'n bemarkingstrategie weergegee.

\section{Bemarkingstrategie}

Marx \& Bolt (1983:27) omskryf 'n bemarkingstrategie soos volg: 'Die doelbewuste en doelgerigte besluite, bestaande uit produk-, distribusie-, bemarkingskommunikasie- en prysbesluite, deur die bemarkingsbestuur, ten einde tydig, ekonomies en doeltreffend by die heersende en verwagte geleenthede en/of bedreigings in die bemarkingsomgewing aan te pas'. Uit die omskrywing van 'n bemarkingstrategie blyk dit dat die daarstelling van die navorsingsresultate in die vorm 'n bemarkingstrategie daartoe sal lei dat bemarkingsinligting die motorfietsbedryf op 'n geordende wyse bereik en sodoende bydra tot die winsgewende voortbestaan van die bedryf.

Aan die hand van die skrywers Evans \& Berman (1985:65) en Lucas (1983:595) kan aangevoer word dat 'n bemarkingstrategie in wese uit die volgende komponente bestaan: 
Tabel 2 Demografiese eienskappe van steekproefrespondente

\begin{tabular}{|c|c|c|}
\hline Demografiese eienskap & $\begin{array}{c}\text { Aantal } \\
\text { respondente }\end{array}$ & Persentasie \\
\hline \multirow[t]{2}{*}{$\begin{array}{l}\text { Geslag } \\
\text { Manlik } \\
\text { Vroulik }\end{array}$} & $\begin{array}{r}105 \\
35\end{array}$ & $\begin{array}{l}75,0 \\
25,0\end{array}$ \\
\hline & 140 & $100 \%$ \\
\hline \multirow[t]{2}{*}{$\begin{array}{l}\text { Ouderdon } \\
\text { Onder } 25 \text { jaar } \\
25 \text { tot } 34 \text { jaar } \\
35 \text { tot } 44 \text { jaar } \\
45 \text { tot } 54 \text { jaar } \\
\text { Bo } 54 \text { jaar }\end{array}$} & $\begin{array}{r}16 \\
77 \\
34 \\
12 \\
1\end{array}$ & $\begin{array}{r}11,4 \\
55,0 \\
24,3 \\
8,6 \\
0,7\end{array}$ \\
\hline & 140 & $100 \%$ \\
\hline \multirow[t]{2}{*}{$\begin{array}{l}\text { lnkomw } \\
\text { R8 } 000 \text { tot R11 } 999 \mathrm{p} . \mathrm{j} \\
\text { R12 } 000 \text { tot R15 } 999 \mathrm{p} . \mathrm{j} . \\
\text { R16 } 000 \text { tot R19 } 999 \mathrm{p.j} \\
\text { R20 000 tot R23 } 999 \mathrm{p.j} . \\
\text { R24 000 tot R27 } 999 \mathrm{p.j} \text {. } \\
\text { Bo R28 000 p.j. }\end{array}$} & $\begin{array}{r}81 \\
30 \\
12 \\
8 \\
7 \\
2\end{array}$ & $\begin{array}{r}57,9 \\
21,4 \\
8,6 \\
5,7 \\
5,0 \\
1,4\end{array}$ \\
\hline & 140 & $100 \%$ \\
\hline \multirow[t]{2}{*}{$\begin{array}{l}\text { Uuwelikstilus } \\
\text { Ongetroud } \\
\text { Getroud } \\
\text { Geskei } \\
\text { Weduwee/Wewenaar }\end{array}$} & $\begin{array}{r}14 \\
116 \\
6 \\
4\end{array}$ & $\begin{array}{r}10,0 \\
82,8 \\
4,3 \\
2,9\end{array}$ \\
\hline & 140 & $100 \%$ \\
\hline \multirow[t]{2}{*}{$\begin{array}{l}\text { Opvocdingspeil } \\
\text { Gedeeltelike hoërskool } \\
\text { Voltonide hoërskool } \\
\text { Tegniesc opleiding } \\
\text { Technikon } \\
\text { Universiteit }\end{array}$} & $\begin{array}{r}17 \\
68 \\
38 \\
13 \\
4\end{array}$ & $\begin{array}{r}12,1 \\
48,6 \\
27,1 \\
9,3 \\
2,9\end{array}$ \\
\hline & 140 & $100 \%$ \\
\hline
\end{tabular}

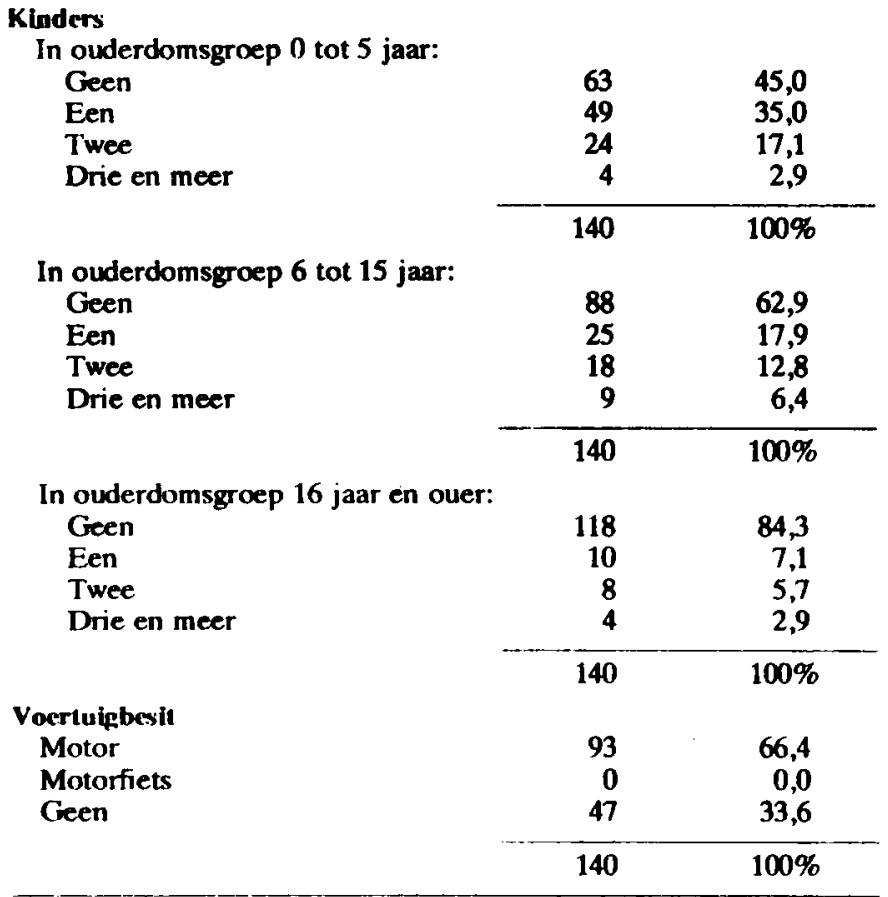

Bron: Bevindings gegrond op navorsingsresultate.

1. 'n Situasie ontleding;

2. 'n missie;

3. bemarkingsdoelwitte;

4. beleidsformulering;

5. die doelmarkkeuse;
6. die bemarkingsresepstrategie;

7. bemarkingstaktiek; en

8. die evaluering van resultate.

Die bevindings van die navorsingsprojek word vervolgens aan die hand van die voorgaande uiteensetting van die komponente van 'n bemarkingstrategie weergegee. Laasgenoemde twee komponente van 'n bemarkingstrategie word egter nie in hierdie artikel beskryf nie aangesien die aktiwiteite verbonde aan hierdie komponente hoofsaaklik by die onderskeie plaaslike invoerders in die motorfietsbedryf berus.

\section{Situasle-ontleding}

Uit die omgewingsanalise wat vir die doel van die studie gedoen is, blyk dit dat die motorfietsbedryf die volgende bedreigings in die mark te wagte kan wees:

(a) 'n Verhoging in motorfietspryse op die Suid. Afrikaanse mark as gevolg van die nadelige Rand/ Yenwisselkoers op die wêreldvalutamark;

(b) die huidige resessie in Suid-Afrika wat gepaard gaan met hoë werkloosheid en sodoende beide die blanke en swart mark se besteebare inkome beperk; en

(c) die hoë ledetal van die gemiddelde swart huisgesin, wat lei tot ' $n$ afkeur in die gebruik van 'n motorfiets as vervoermiddel, aangesien dit slegs vervoer aan een tot twee van die huisgesin se lede, per geleentheid bied.

Eersgenoemde twee bedreigings behoort te verdwyn namate die Suid-Afrikaanse ekonomie versterk.

Deur' $n$ beklemtoning van die volgende voordele van motorfietse, bo dié van mededingende vorme van vervoer, kan die motorfietsbedryf die laasgenoemde bedreigings oorbrug, naamlik:

(a) Motorfietse is meer brandstofekonomies as motors;

(b) motorfietse bied die geleentheid om 'n eie vervoermiddel teen 'n laer aankoopprys as motors te besit;

(c) motorfietse se lisensiegelde is aansienlik laer as dié van motors; en

(d) deur die gebruik van motorfietse as vervoermiddels kan die ongerief en diefstalgevaar verbonde aan die gebruik van openbare vervoer vermy word.

Daar is ook verskeie geleenthede geidentifiseer wat deur die motorfietsbedryf benut kan word. Die langtermyn geleenthede behels hoofsaaklik die volgende:

(a) Die hoë verstedelikingskoers van die swart bevolking, wat hulle blootstel aan 'n hoër mate van verwesterliking, en dus meer vatbaar maak vir die motorfietskonsep;

(b) die elektrifisering van swart woongebiede, wat 'n motorfietsbemarker in staat stel om makliker deur middel van televisiereklame met die swart mark te kommunikeer; en

(c) die verhoging in die opvoedingspeil van swartes wat gepaard gaan met 'n verhoging in die totale koopkrag van die swart mark.

Twee korttermyn geleenthede is ook geidentifiseer, naamlik:

(a) Die wysiging in die Wet op Huurkope, wat 'n verlaging in die aanvanklike deposito, asook 'n 
verlenging in die terugbetalingstermyn tot gevolg gehad het; en

(b) die verlaging in rentekoerse, wat lei tot 'n verlaging in die terugbetalingsbedrag by huurkope.

Deur die voorgenoemde bedreigings te omseil en geleenthede te benut behoort die motorfietsbedryf in staat te wees om suksesvol tot die swart mark toe te tree. Vervolgens word aspekte beskryf wat sal bydra tot die geslaagdheid van die toetredingspoging.

\section{Missie van die motorfietsbedryf}

Uit die bevindings van die studie het dit geblyk dat die missie van die motorfietsbedryf in die swart mark soos volg moet lui, naamlik die daarstelling van 'n ekonomiese vervoermiddel, in die pendelaarsklas (200 $\mathrm{cm}^{3} .500 \mathrm{~cm}^{3}$ ), wat brandstofekonomies funksioneer en swartes in staat stel om 'n eie vervoermiddel te besit.

Ten cinde uiting te gee aan die missie behoort die motorfietshedryf bepaalde bemarkingsdoelwitte te formuleer.

\section{Formulering van bemarkingsdoelwitte}

Die volgende bemarkingsdoelwitte kan vir die motorfietsbedryf geformuleer word:

(a) Om die jaarlikse verkope van die motorfietsbedryf tot ongeveer 25000 eenhede te verhoog ten einde die winsgewende voortbestaan van die bedryf te verseker;

(b) om 'n verhoging in die jaarlikse verkope te bewerkstellig deur tot die swart mark toe te tree; en

(c) om verkope aan die swart mark te bewerkstellig deur die daarstelling van 'n produk-, distribusie-, bemarkingskommunikasie- en prysstrategie wat optimaal in die swart mark se behoeftes en voorkeure sal voorsien. Elk van die genoemde vier strategieë sluit bepaalde doelwitte en riglyne in wat uitgevoer behoort te word ten einde verkope aan die swart mark te verhoog. Alvorens hierdie vier strategieë, asook die doelmark tot wie hierdie strategieë gerig moet word, beskryf kan word, is dit belangrik om eers bemarkingsbeleidsriglyne vir die motorfietsbedryf te formuleer.

\section{Formulering van beleidsriglyne}

Die bemarkingsbeleid is riglyne wat neergelê moet word vir die beplanning en uitvoering van en beheer oor die bemarkingstrategie. Aan die hand van die studie kan die volgende as riglyne vir beleid binne die motorfietsbedryf gestel word, naamlik:

(a) Dat die owerhede, die Vereniging van Motorfietsinvoerders en Verspreiders (AMID), en die onderskeie handelaars in die bedryf, gekoördineerd moet optree ten opsigte van aspekte soos

- die invoerbelasting op motorfietse; invoerpermitte vir motorfietse;

die fisiese verspreiding van motorfietse, byvoorbeeld die verkryging van padvervoerpermitte; en

- die daarstelling van wetgewing oor die motorfietsbedryf. (b) Dat etiese verkoopstegnieke in die swart mark aangewend moet word.

(c) Dat daar nie van 'n stortingstrategie in die motorfietsbedryf gebruik gemaak moet word nie.

(d) Dat dieselfde model motorfiets aan alle handelaars teen dieselfde prys gelewer moet word.

(e) Dat kredietfinansiering op 'n gelyke grondslag vir alle bevolkingsgroepe gereël moet word.

(f) Dat alle handelaars slegs motorfietse vanaf die plaaslike invoerders moet aankoop en nie self invoer nie.

(g) Dat produkte aan handelaars soos deur hulle aangevra, en nie volgens die denke van die plaaslike invoerders nie, gelewer moet word.

(h) Dat die swart mark nie weens hul gebrekkige kennis oor motorfietse uitgebuit moet word nie.

(i) Dat prysoorloë in die bedryf ontmoedig moet word, met behoud van gesonde mededinging.

(j) Dat soveel moontlik inligting aan die Swartmark in hul eie taal, oor motorfietse, beskikbaar gestel moet word.

Die onderskeie plaaslike invoerders behoort telkens, na gelang van hul bepaalde situasie, ' $n$ bemarkingsbeleid binne die voorgaande riglyne te formuleer. Vervolgens word 'n beskrywing van 'n aangewese doelmark, vir die toetrede tot die swart mark, daargestel.

\section{Doelmarkkeuse}

Ten einde die heterogene mark in homogene groepe te verdeel, word die marksegmenteringsproses toegepas. Deur die toepassing van die marksegmenteringsproses word die motorfietsbedryf in staat gestel om 'n bepaalde doelmark te identifiseer tot wie die bemarkingspoging gerig kan word. Tabel 3 is 'n voorstelling van die doelmark wat die motorfietsbedryf kan gebruik as uitgangspunt vir die toetrede tot die totale Suid-Afrikaanse swart mark.

Uit Tabel 3 blyk die geografiese, demografiese, en psigografiese eienskappe van die doelmark, wat die motorfietsbedryf behoort te benut as uitgangspunt met hul toetrede tot die Suid-Afrikaanse Swartmark. Die psigografiese eienskappe van die marksegment hou tans die grootste bedreiging vir die motorfietsbedryf in, veral weens swartes se huidige negatiewe ingesteldheid teenoor motorfietse.

Die negatiewe ingesteldheid is gegrond op die gevaarkonnotasie wat swartes heg aan die gebruik van 'n motorfiets as 'n vervoermiddel. Die motorfietsbedryf moet dus daarop ingestel wees om die negatiewe beeld te omskep in 'n positiewe beeld. Ten einde 'n positiewe beeld in die swart mark op te bou, behoort die motorfietsbedryf swartes se bekouing van 'n motorfiets te wysig, en wel van 'n gevaarlike, hoëspoedproduk wat deur jaagduiwels gebruik word, na 'n hoogs ekonomiese vervoermiddel wat aan swartes die geleentheid bied om 'n eie vervoermiddel te besit.

Met die beskrywing van die doelmark as agtergrond, kan daar voortgegaan word met die daarstelling van 'n bemarkingsresepstrategie wat deur die motorfietsbedryf benut kan word tydens hul toetrede tot die swart mark. 
Tabel 3 Doelmark wat vir die motorfietsbedryf identifiseer is

\begin{tabular}{|c|c|}
\hline Segmenteringsgrondslag & Beskrywing \\
\hline \multicolumn{2}{|l|}{ Gcogrufies } \\
\hline Provinsie & Transvaal-meeste swartes $\pm 5,6$ miljoen \\
\hline Streek & Streek $19- \pm 1,6$ miljoen stedelike swartes \\
\hline Bevolkingsdigtheid & $\begin{array}{l}\text { Stedelik-onderworpe aan die hoogste } \\
\text { mate van verwesterliking }\end{array}$ \\
\hline Klimaat & Binnelands-hoë somerstemperature \\
\hline \multicolumn{2}{|l|}{ Demografies } \\
\hline Ras & Swart \\
\hline Geslag & $\begin{array}{l}\text { Manlik-gebruiker; Vroulik-heroriënteer } \\
\text { negatiewe beskouing tot 'n positiewe } \\
\text { aanvaarding van die motorfietskonsep }\end{array}$ \\
\hline Ouderdomstruktuur & 16 jaar tot 34 jaar \\
\hline Opvoedingspeil & $\begin{array}{l}\text { Matriek en hoêr-beskik oor voldoende } \\
\text { fondse (kredietwaardig) }\end{array}$ \\
\hline Inkomste & Bo R8 000 per jaar-kredietwaardig \\
\hline Taal & Sotho, Zoeloe, en Shangaan \\
\hline Gesinne & Alle groottes \\
\hline Geloof & Alle gelowe \\
\hline Sosiale klas & Laer-middelklas tot middelklas \\
\hline \multicolumn{2}{|l|}{ Psigografies } \\
\hline Verbruikerskoers & Tans bykans geen \\
\hline $\begin{array}{l}\text { Gereedheid om te } \\
\text { koop }\end{array}$ & $\begin{array}{l}\text { Nie gereed nie - vereis eers die vestiging } \\
\text { van 'n positiewe boeld van die } \\
\text { motorfietskonsep in die swart mark }\end{array}$ \\
\hline Voondele nagestreef & $\begin{array}{l}\text { Ekonomiese vervoer, ontduiking van } \\
\text { verkeersknope en parkeerprobleme }\end{array}$ \\
\hline Soort verbruiker & Potensièle verbruiker \\
\hline Lojaliteit & Tans bykans geen teenoor motorfietse \\
\hline Persoonlikheid & Nie impulsief nie - stadige koper \\
\hline Lewenstyl & Beskou vervoermiddel as statussimbool \\
\hline
\end{tabular}

Bron: Afleidings is gegrond op die bevindings van die navorsingsprojek.

\section{Ontwikkeling van 'n bemarkingsresepstrategle vir die motorfietsbedryf}

Aangesien die motorfietsbedryf 'n nuwe doelmark betree word 'n nuwe produk-, distribusie-, bemarkingskommunikasie-, en prysstrategie vereis ten einde 'n suksesvolle toetrede tot die swart mark te verseker. Vervolgens word die kritiese punte van elk van die vier genoemde strategieé onderskeidelik daargestel. Die onderskeie bemarkers in die motorfietsbedryf behoort gehoor te gee aan hierdie riglyne tydens hul toetrede tot die swart mark.

\section{Produkstrategie}

Motorfietse wat aan die swart mark beskikbaar gestel word behoort, volgens die bevindings van die navorsingsprojek, oor die volgende eienskappe te beskik ten einde aan swartes se voorkeure en behoeftes te voldoen: (a) Brandstofekonomiese werkverrigting;

(b) 'n enjinkapasiteit tussen $200 \mathrm{~cm}^{3}$ en $500 \mathrm{~cm}^{3}$;

(c) 'n hoë kwaliteit;

(d) drie kleurkeuses, en wel swart, rooi en blou;

(e) reeds aangehegte windskerms, aangesien $83 \%$ van die steekproefrespondente 'n sodanige voorkeur het;

(f) 'n konvensionele styl, dit wil sê geen wedrenstylmodifikasies nie; en

(g) die beskikbaarheid van sykantbagasiehouers as 'n opsionele ekstra.

\section{Distrlbusiestrategie}

Ten einde die swart mark optimaal te bedien behoort 'n distribusiestrategie die volgende eienskappe te vervat:

(a) Handelaars wat in motorfietsverkope en naverkoopdienste spesialiseer;

(b) handelaars wat in blanke industrièle gebiede, byvoorbeeld die Oos-Rand, geleë is (aangesien groot hoeveelhede swartes in hierdie gebiede werksaam is);

(c) 'n distribusiekanaal wat soos volg daaruit sien, naamlik plaaslike invoerder-handelaar-verbruiker,

(d) blanke verkoopspersoneel, terwyl swart verkoopspersoneel geleidelik ingefaseer word;

(e) verkoopspersoneel wat gewillig en in staat is om swartes breedvoerig in te lig aangaande die tegniese eienskappe en werkverrigting van motorfietse; en

(f) handelaars moet oor voldoende nuwe motorfietse beskik, aangesien swartes 'n voorkeur vir nuwe motorfietse bo gebruikte motorfietse het.

\section{Bemarkingskommunikasiestrategle}

Ten einde ' $n$ doeltreffende bemarkingskommunikasiestrategie daar te stel, behoort die motorfietsbedryf die volgende bemarkingskommunikasiedoelwitte na te streef:

(a) Om die swart mark daarvan bewus te maak dat 'n motorfiets hulle in staat sal stel om 'n eie vervoermiddel te besit, deur aan die swart mark uit te wys dat die koste verbonde aan die gebruik van 'n motorfiets mededingend is met die koste verbonde aan die gebruik van die ander vorme van vervoer, naamlik huurmotors, treine, busse, en motors.

(b) Om die gerief verbonde aan die besit van 'n eie vervoermiddel, veral ten opsigte van tydsbesparing, aan die swart mark uit te wys.

(c) Om die gerief verbonde aan die gebruik van 'n motorfiets as vervoermiddel ten opsigte van die ontduiking van verkeersknope en parkeerprobleme, uit te wys.

(d) Om die gevaarkonnotasie wat swartes aan die gebruik van 'n motorfiets as vervoermiddel koppel, af te takel, deur 'n beklemtoning van die bogenoemde voordele van 'n motorfiets as vervoermiddel, en deur aan die swart mark uit te wys dat motorfietsongelukke hoofsaaklik toegeskryf kan word aan roekelose bestuurders wat nie ag slaan op spoedbeperkings nie. 
(e) Om inligting aan die swart mark beskikbaar te stel ten opsigte van die volgende eienskappe van 'n motorfiets:

-- Werkverrigting;

- duursaamheid;

tegnologiese voordele;

- hantering; en

- betroubaarheid.

Die motorfietsbedryf behoort die elemente van bemarkingskommunikasie sodanig aan te wend dat die doelwitte optimaal bereik word. Die elemente van bemarkingskommunikasie kan soos volg aangewend word:

(a) Reklame:
- Radio
: Radio Bophuthatswana vanaf 06h00 tot $08 \mathrm{~h} 30$ en $17 \mathrm{~h} 30$ tot $20 \mathrm{~h} 30$
- Koerante : Die 'Sowetan'-dagblad
-.. Tydskrifte : 'Bona' - hoogste lesertal
- Televisie : TV 1 tussen $18 \mathrm{~h} 00$ en 20h00; moontlik op 'n latere geleentheid TV 4
- Bioskope : Vertoon advertensies in
-- Buitereklame: Die strategiese plasing van advertensieborde in swart woongebiede en op bushaltehokkies

(b) Persoonlike verkope:

Blankehandelaars behoort swart verkoopspersoneel in diens te neem en op te lei ten einde die betrokke swartes in staat te stel om op 'n latere geleentheid handelaars in swart gebiede te open en te bestuur.

(c) Verkoopspromosies:

Die motorfietsbedryf kan van veral twee tipes verkoopspromosies gebruik maak, naamlik:

- 'n Spesiale afslag op motorfietse wat byvoorbeeld gedurende Desember gekoop word; en - geskenke soos byvoorbeeld handskoene, aan alle kopers van motorfietse in ' $n$ bepaalde periode of bo 'n bepaalde prys.

Verkoopspromosies word gebruik om die verbruiker aan te spoor om 'nou' te koop, aangesien daar 'n voordeel aan verbonde is, hetsy in die vorm van 'n geskenk of groter afslag. Verkoopspromosies kan die gevoel by die verbruiker skep dat die bemarker gretig is om sy produkte vinnig te verkoop. Dit kan agterdog wek by die verbruiker dat die produkte nie andersins verkoop kan word nie. Die oormatige gebruik van verkoopspromosies, veral as dit vir lang periodes gebruik word, kan ook 'n soortgelyke gevoel by die verbruiker skep. Die bemarker loop dus die gevaar om die beeld van sy produkte te skaad. Om hierdie redes word aanbeveel dat die motorfietsbedryf nie die bemarkingskommunikasiepoging tot die swart mark met verkoopspromosies moet inlei nie. Verkoopspromosies behoort eers twee tot drie maande na die loodsing van die reklameveldtog gebruik te word, om swartes te oorreed om 'nou' te koop. (d) Publisiteit:

Die motorfietsbedryf kan soos volg te werk gaan ten einde publisiteit te verkry:

- Deur die beskikbaarstelling van 'n artikel aan die pers wat beduidend is op die ekonomiese en ander voordele van 'n motorfiets; en

- deur sportbyeenkomste, soos byvoorbeeld sokkerwedstryde, te borg.

Deur middel van elk van die voorgaande elemente van bemarkingskommunikasie word 'n bepaalde boodskap aan die swart mark oorgedra. Die boodskap behoort sodanig ontwikkel te word dat dit tot die bereiking van die bemarkingskommunikasiedoelwitte sal lei. Voorts behoort die reklameboodskap aan die volgende vereistes te voldoen:

(a) Advertensies behoort die aftakeling van die gevaarkonnotasie wat swartes aan 'n motorfiets heg ten doel te hê, en wel deur aan swartes uit te wys dat daar slegs gevaar verbonde is aan die roekelose gebruik van 'n motorfiets en nie aan die normale gebruik nie.

(b) Die aanwakkering van swartes se behoefte aan 'n eie vervoermiddel, deur die ekonomiese voordele verbonde aan die gebruik van 'n motorfiets as vervoermiddel aan die swart mark uit te wys. 'n Konvensionele styl motorfiets behoort vir die doel van advertensies gebruik te word, aangesien dit die beeld van ekonomiese vervoer sal versterk.

(c) Die boodskap behoort gerig te wees tot die swart huishouding ten einde almal vertroud te maak met die motorfietskonsep en sodoende 'n positiewe beeld op te bou.

(d) Die advertensie behoort nie te sentreer om die nuutste en mees tegnologies gevorderde motorfiets nie, maar om die vereenselwiging van die motorfietskonsep met swartes se lewenstyl en persoonlikheid.

Deur gehoor te gee aan die voorgaande riglyne behoort die motorfietsbedryf in staat te wees om suksesvol met die swart mark te kommunikeer.

\section{Prysstrategle}

'n Prysstrategie vir die bereiking van die swart mark behoort oor die volgende eienskappe te beskik:

(a) 'n Relatiewe lae toetredingsprys tot die swart mark, aangesien motorfietse vraagelasties is, met die implikasie dat ' $n$ laer prys sal lei tot ' $n$ verhoging in verkope;

(b) motorfietse in die R4000 en minder prysklas, wat aan swartes se prysvoorkeure sal voldoen; en

(c) die beskikbaarheid van kredietfinansieringsfasiliteite, aangesien die meerderheid swartes motorfietse op krediet sal aankoop, veral weens hul relatiewe lae jaarlikse inkomste.

\section{Slot}

Deurdat die onderskeie bemarkers in die motorfietsbedryf die riglyne wat in hierdie artikel vervat is, inkorporeer met hul eie ondernemings se doelwitte en 
strategië behoort hulle in staat te wees om suksesvol tot die swart mark toe te tree.

\section{Summary}

The South African motor-cycle industry has experienced a constant decline in sales since 1981, that is, a drop from 84000 units sold during 1981 to a sales figure of 24509 for 1985. This decline in sales poses a threat to the profitability and survival of the motor-cycle industry in South Africa.

Up to this point in time the marketing efforts of the motor-cycle industry have been mainly directed towards the white consumer market. In order to bring about an upturn in motor-cycle sales, this study looked into the feasibility of a marketing effort, by the motor-cycle industry, aimed at the black consumer market.

The aim of the empirical research can be stated as follows, namely:

(a) To determine blacks' attitude towards motor-cycles as a mode of transport; and

(b) to determine blacks' needs and preferences with regard to aspects such as the product, distribution outlets, price, and marketing communication.

Information was collected by distributing questionnaires to a random sample of blacks in region nineteen according to the Standard code list for statistical main regions and regions, magisterial districts, cities, towns, and non-urban areas. The following municipal districts are included in region nineteen: Johannesburg, Randburg, Germiston, Alberton, Kempton Park, Boksburg, Benoni, Brakpan, and Springs. This particular area was chosen mainly owing to the fact that it currently represents approximately $50 \%$ of the motorcycle industry's market.

The potential of the black market has been disregarded by the motor-cycle industry because of the belief that blacks are opposed to motor-cycles as a result of their cultural traditions. Although this may have been the case until recently, the following factors could bring about a change in the way in which blacks perceive motor-cycles:

(a) The increase in the petrol price;

(b) the change in the life-style of blacks due to westemization; and

(c) an increasing desire among blacks to obtain their own means of transport.

The research project was conducted in the light of the aspects mentioned in the preceding paragraphs. The findings of the study were presented in the form of a marketing strategy. In the subsequent paragraphs the more critical findings of the study are stated.

As far as the geographical and demographical characteristics of the market are concerned, no real threats to the motor-cycle industry could be traced. However, as far as the psychographical characteristics of the market are concerned, certain threats were identified. The threats can be summarized as follows: Blacks have a negative attitude towards motor-cycles as a mode of transport, and view motor-cycles as a dangerous means of transport, mainly used by high speeding dare-devils.
In order to bring about a change in blacks' attitude towards motor-cycles, the motor-cycle industry should bring the following attributes of motor-cycles to the attention of blacks:

(a) Motor-cycles function more fuel-efficiently than motor-cars;

(b) motor-cycles have lower licence fees than motorcars;

(c) motor-cycles can provide blacks with the convenience of owning their own means of transport at a relatively low purchase price, compared to motorcars, and thereby overcome the inconvenience attached to public transport; and

(d) the use of motor-cycles as a mode of transport can alleviate traffic jams and parking problems.

In addition to bringing the above attributes of motorcycles to the attention of blacks, the motor-cycle industry should develop a marketing mix strategy which will comply with the needs and preferences of blacks. The marketing mix strategy consists of the product, distribution, marketing communication, and price strategies. The unique characteristics of each of these four strategies is stated in the following paragraphs.

The marketing communication strategy should centre on the re-education of blacks so that they perceive motor-cycles as an economical means of transport, requiring little parking space, instead of as heavy metal terrorists' with horrifying accident records. Subsequently, the product offered to the black market should reveal its economical characteristics and, as preferred by blacks, be in the commuter class $\left(200 \mathrm{~cm}^{3}-500 \mathrm{~cm}^{3}\right)$.

It seems that blacks still have a preference for distribution outlets in white areas with white sales personnel. The findings of the study indicated that distribution outlets in industrial areas, where many blacks are employed, would place motor-cycles within the reach of the black market. The price should not exceed R4000 as blacks still fall within the lower income groups. With prices above $\mathbf{R} 4000$, the majority of blacks could experience difficulty in obtaining credit, and develop a preference for allocating their money towards the purchase of a motor-car.

In conclusion, it can be stated that by informing the black consumer market of the ability of a motor-cycle to provide them with a private economical means of transport, which is only dangerous when used recklessly as any other means of transport would be, the motor-cycle industry would be able to bring about an upturn in its annual sales. Thus, by awakening the black market's needs for a motor-cycle as a means of transport, the motor-cycle industry could assure their profitability and survival in South-Africa.

\section{Verwysings}

Booyens, G. Algemene bestuurder, motorfietsafdeling, Midmacor Honda. Persoonlike onderhoud.

Cochran, W.G. 1963. Sampling Techniques, 2de uitgawe. New' York: John Wiley \& Sons, Inc.

Evans, J.R. \& Berman, B. 1985. Marketing, 2de uitgawe. New York: Macmillan Publishing Company. 
Heinz, A. Gewese Streeksvoorsitster - Suid-Transvaalstreek van die Motorfietsinvoerders en Handelaars Vereniging (MCIDA). Persoonlike onderhoud.

Lucas, G.H.G. (red.) 1983. Die taak van die bemarkingsbestuur. Pretoria: J.L. van Schaik.

Marx. S. \& Bolt. J. 1983. Bestuurstrategie en produkbeshite.
Kaapstad: Juta \& Kie.

Sentrale Statistiekdiens. 1985. Statistiese Nuusberig. Pretoria: Bevolkingsensus 6 Maart 1985. p.11.

Winfield, B. 1985. Barry Winfield looks at the state of the motor-cycle industry. Wheels 4. Johannesburg: Creda Press. 131- 133. 